\title{
Put a Tiger in Your Text
}

\author{
Metalepsis and Media Discourse ${ }^{l}$
}

\author{
Leif Dahlberg
}

\begin{abstract}
The subject of this article is the extensive use of metalepsis as an argumentative and rhetorical device in media discourse, and in particular in advertising. Metalepsis, a form of metonymy, sets up an inverted relation - causal, logical or contiguous - between terms and/or objects, either as an aesthetic effect or a means of persuasion. The first part of the article discusses the use of metalepsis in literature and film; the second part discusses the use of the figure in mass media and advertising; the third part discusses the relation between advertising, art, and popular culture. The final part of the article discusses the pervasive use metalepsis in advertising. Since metalepsis is a powerful rhetorical device, I have chosen the figure of the tiger to illustrate how it operates in advertising and media discourse.
\end{abstract}

Keywords: advertising, metalepsis, metonymy, rhetoric, media discourse

\section{Introduction}

Tyger! Tyger! burning bright,

In the forests of the night;

What immortal hand or eye,

Could frame thy fearful symmetry?

(William Blake, Songs of Experience (1794), 'The Tiger')

In Aristotle's classic treatise on the art of rhetoric, the art (techne) is defined as the ability (dynamis) to see (theoresai) what the possible means of persuasion (endekhomenon pithanon) are in every given case, the means of persuasion being categorised into the use of reason (logos), feeling (pathos) or the invocation of the speaker's character (ethos) (Ars rhetorica I.ii.1-3; 1355b). Although other and later definitions of rhetoric have emphasized instead the aspect of speaking in front of an audience, or simply speakíng (or writing) well, the role of persuasion has always remained central to rhetorical thinking. For this reason, if for no other, rhetoric is a key concern for merchants and traders of goods, services or ideas. In the long history of Western rhetoric, many schemes for persuasion have been devised, in the form of conceptual schemes (figures of thought) or turns of phrases (figures of discourse). Of the many ways of discursive persuasion, certainly one of the most important tropes deals with the movement from one thing to another, or from one part of a thing to another part of the same thing. The movement may be one of cause and effect (causal relation), logical implication (necessary relation), or 
simply of contiguity. The name most commonly used in rhetoric to denote these kinds of discursive movements is metonymy.

There are a number other terms used to single out specific kinds of metonymic movements, for instance synecdoche defines the relation (or movement) between part and whole, as when the word 'sail' denotes a ship, or 'head' denotes the brain or mental faculty of a person. In this article, I will discuss the figure of inverted (causal, logical, contiguous) relations between terms and/or objects used as a means of persuasion. Inverted causal relation defines the situation where the effect precedes the cause, for instance when the (perceived) effect is the (real or actual) cause or when the (real) cause is presented as the effect. In inverted (onto)logical relations, the distinction between substance and accident, figure and ground, original and copy is either reversed, confused or extinguished. This (inverted) form of metonymy usually goes by the name of metalepsis. The argumentative use of this kind of inverted - some would say perverted - causal relation is obviously quite important when appealling to peoples' desire or when reasoning about what people (really) want. In other words, if advertising is the art of making people understand what they need (and always wanted) and to make them act on this insight, then the persuasive use of metalepsis is a key element in advertising discourse. It is strange that the name of this figure of thought is so little known in an age that prides itself on being a consumer culture or even an age of consumerism.

Metalepsis, like most rhetorical figures, has been defined in different ways throughout history (Burkhardt 2001: 1087-1099; Roussin 2005: 37-58). According to the French eighteenth century rhetorician Dumarsais (1676-1756), metalepsis designates "a form of metonymy, by which one explains what follows in order to denote what precedes; or what precedes in order to denote what follows" (Dumarsais 1988: 110). ${ }^{2}$ Metalepsis is used either as an indirect expression (as allusion, euphemism or litothesis) or as a way to give greater weight to an expression, as when the poet instead of a description "places in front of our eyes the fact that the description presupposes" (Dumarsais 1998: 114). ${ }^{3}$ In the latter form, as in hypotyposis or tableau, metalepsis designates a fictional expression, i.e. a kind of fiction.

These two uses of the figure recur in Pierre Fontanier's (1768-1844) Les Figures $d u$ discours (1830), but here metalepsis and metonymy are seen as distinct. Fontanier designates metalepsis as a kind of substitution where an indirect expression replaces a direct one, i.e. "to denote one thing by another, which precedes it, follows it or accompanies it, is adjacent to it, a circumstance of some kind, or finally is connected with or corresponds to in a manner to immediately bring it to mind" (Fontanier 1977: 127-128). ${ }^{4}$ An interesting variant of metalepsis in Fontanier, called "metalepsis of the author", consists of a figurative inscription of the speech act: "the figure by which a poet, a writer, is represented or represents himself as producing himself that which he in reality only is narrating and describing" (Fontanier 1977: 128). ${ }^{5}$ In this variant of the figure, the act of writing has itself become a stage, just as in hypotyposis. In Fontanier, in contrast to in Dumarsais, this figure has become a reflexive trope where one uses a factual proposition in order to strengthen the effects of a fiction (Roussin 2005: 43, 51). 


\section{Narrative Metalepsis}

In the name of metalepsis, one can explore the different forms through which literary discourse oversteps its own thresholds, internal and external, violating our ordinary conceptions of reality (time, space and causality). In literary studies, metalepsis has increasingly come to be seen not only as an important device operating between the literary act and the literary discourse it produces, between this and the secondary discourse it encloses, but also as providing a foundation for fictional discourse as such. However, it is primarily within the modern study of narrative - narratology - that metalepsis has been systematically investigated. According to the definition by Gérard Genette, narrative metalepsis consists of a transgression of the border between diegesis and metadiegesis, as when the narrator enters the story he is telling (or inversely that the characters in the story step out of the metadiegesis) (Genette 1972: 243-251). An often cited example is found in Julio Cortásar's short story Continuidad de los parques (1956). In this story there is a description of a man reading a book. He is sitting in an easy-chair in the library of a house surrounded by a garden. In the book he is reading there is a meeting between two lovers who decide to kill the woman's husband. The male lover departs and after a while arrives at a house surrounded by a garden. He enters the house and in the library he finds a man sitting in a chair reading a book. The narrative ends here and it is left to the reader of Cortásar's story to decide whether the man reading the book is also the woman's husband and to imagine what might happen next. Although in this case the narrative metalepsis is implicit and indirect, the figure always violates the illusion of realism, either playfully and rhetorically or, as in this example, seriously and ontologically. Yet at the same time as the figure creates a sense of unreality, it brings the reader closer to or even into the fiction. The paradox of metalepsis is that it simultaneously violates our sense of logic and order and gives the reader an acute experience of the reality of (the) media.

Before proceeding further, I would like to give a few more examples of uses of the figure. In the final scene in Charlie Chaplin's film The Great Dictator (1940), the barber in the ghetto (played by Chaplin) gives a passionate speech in defence of democracy and tolerance. ${ }^{6}$ The scene breaks with the mode and tone of the rest of the film and marks a shift from satire to pathos, from caricature to political agitation. Apart from the divergent element of propaganda in a fiction film, the barber appears in this scene as a thinly veiled mask of Chaplin himself. It might at first seem to be a merging of extra-diegesis and diegesis where the scriptwriter and film director is represented in his own work. However, the film metalepsis does not consist of an overstepping of the separation of narrator and narrated, but of that between actor (Chaplin) and character (barber). As has been pointed out by Jean-Marie Schaeffer, in this scene the metalepsis is not instantaneous (as it usually is in literature) but progressive: the visual and auditive experience of the speech creates a gradual metamorphosis, and Chaplin appears from the barber little by little (Schaeffer 2005: 327). A curious aspect of the metalepsis in The Great Dictator is that although the two sides of the figure (the barber and Chaplin) are superimposed, they still remain separate and distinguishable. One can compare Chaplin's use of this device with the use of parabasis in classic Greek comedy. In Aristophanes' Clouds (the revised and only extant version), the chorus leader steps out of his role in order to address the audience directly and to comment on the reception of the staging of the first version of the play (Aristophanes 1998: lines 518-562). ${ }^{7}$ Although in this particular case, 
parabasis does not entail a collapse of the separation of diegetic levels associated with metalepsis, in many cases it does. ${ }^{8}$

Another example of narrative metalepsis, also from a fiction film, is found in Howard Hawks' His Girl Friday (1940). ${ }^{9}$ In this film, the character Walter Burns (played by Cary Grant) is asked to give a description of his rival. Burns states that he resembles the actor Ralph Bellamy. So far, there is nothing remarkable in the description. However, later in the film the spectators get to see Burns' rival, and it turns out that he not only resembles Bellamy but is acted by him. In comparison with Chaplin's The Great Dictator, the metalepsis in Hawks' film is lighter, more a joke than a powerful device to secure the spectator's attention in order to deliver a serious message. Although metalepsis as such is a striking and forceful figure, the employment can be allusive and playful. Yet regardless of whether in earnest or in jest, metalepsis effects a topicalization of the medium.

\section{Media Metalepsis}

Metalepsis is, however, not only a literary and narrative device. The figure is recurrent both in mass media discourses and in media as system. ${ }^{10}$ In mass media, metalepsis is often used as a communicative device to produce immersion and a heightened sense of reality. For my first example of metalepsis in media discourse, we will stay within the film medium but leave the world of fiction and take a look at television news. Just as in the case of fiction film, in the production of television news there is a convention that one should not show the set or the studio as such (with lighting, microphones, cameras, prompter), but only the news desk. To use the theatre metaphors popularized by the sociologist Erving Goffman, one is shown the front region of the television production, whereas the offstage or back region (costume, make-up, teleprinters, work space, etc.) is hidden from view (Goffman 1969: 100 ff.; Goffman 1986: 123-155). However, the absolute division between news production (back region) and newscasting (front region) has gradually become more permeable. In the 1990s the impenetrable wall separating the two realms was frequently replaced by a transparent glass window, and the television studio was presented as connected to an actual news room where information was continuously streaming in, analysed, and evaluated. The effect of this merging of front region and back region is directly opposite to metalepsis in fiction: instead of creating a sense of unreality, it enhances the sense of reality of the front region. One could even use the term "reality effect" to describe the meaning of metalepsis in newscasting (Barthes 1968).

As rhetorical figure, metalepsis can be found in all kinds of mass media, but nowhere is the figure as important as in advertising. The typical form of metalepsis in advertising media presents the consumer with the future effects of a purchase (Roque 2005: 276). These future effects of consumption can either be presented as material or social, real or imagined. The effects may furthermore be depicted either directly (e.g. by an image of a smoking man surrounded by attractive women) or indirectly (e.g. by showing an image of a masculine man riding a horse, as the "Marlboro cowboy"). ${ }^{11}$ Depending on the modality of the presentation, one could say that advertisement employs the verb tense forms modal perfect or future perfect (often hypothetical).

I will illustrate this use of metalepsis by discussing a well-known 1960s advertising campaign for Esso (later Exxon), representing a tiger, with the copy "Put a tiger in your tank!" (see figure 1). 


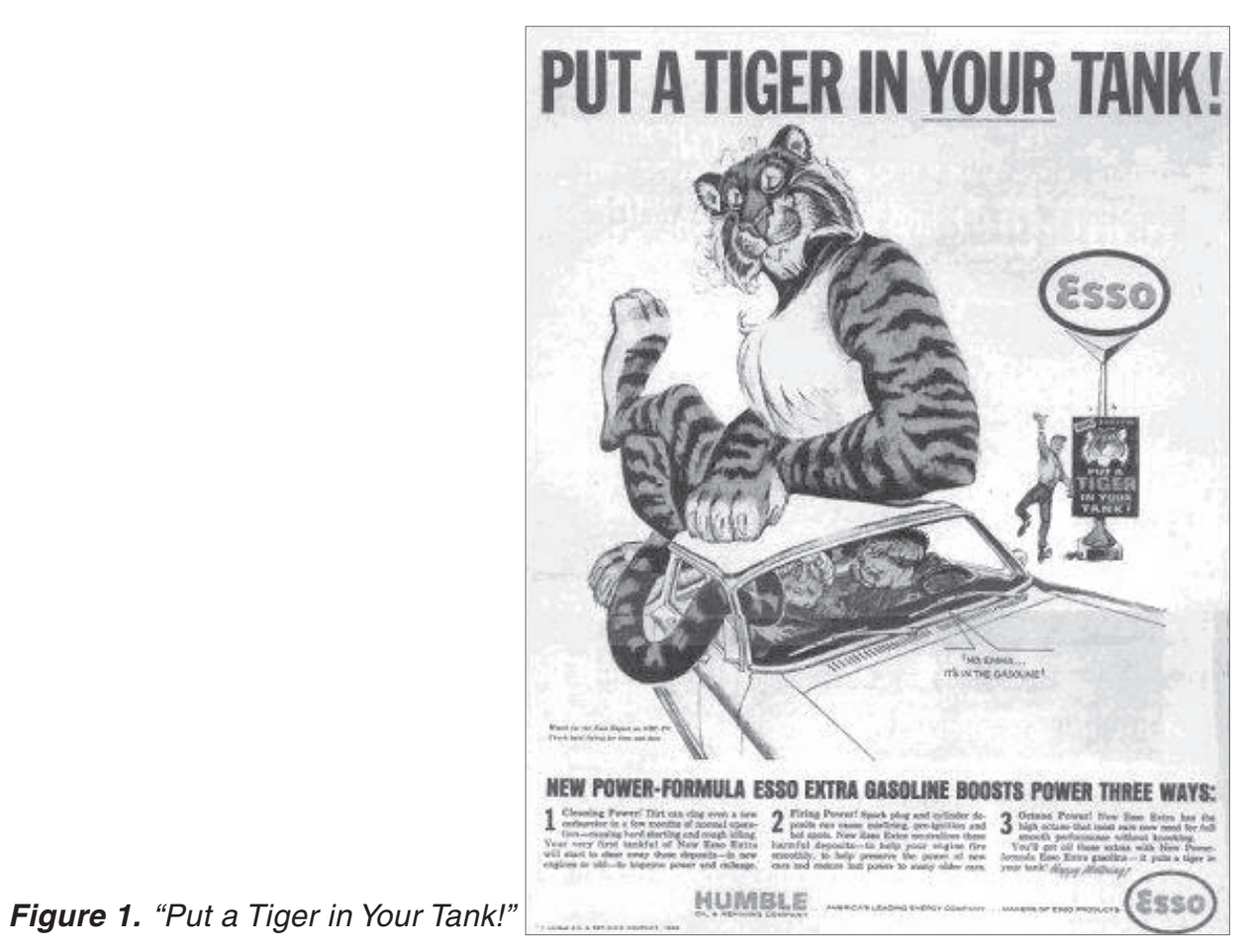

Although the meaning of the advertisement is fairly obvious, the rhetorical logic is more complex. The figurative meaning of the tiger is primarily metaphorical, representing strength and power. In contrast to the metaphorical expression "Achilles is a lion", where the analogy with the lion implies not only power but also courage and aggressiveness, the Esso tiger is a smiling and friendly character, tuning down or even negating the aggressive aspect of the metaphor. In the image above, the Esso tiger is furthermore anthropomorphized to the extent that its left front leg has the form of a human arm with bulging biceps. However, the connection between the friendly tiger and the product (petrol) is not metaphorical but metaleptic (or metonymic): the effect of putting Esso petrol in "your tank" is that it will make your engine more powerful and that your car will behave like a tiger (albeit a friendly and not fearful one). The tiger represents the metaphorical future effect of putting Esso petrol in your tank. In other words, in the advertisement the tiger constitutes a visual metalepsis.

The use of metalepsis in advertisement is so predominant that one can argue that advertising as media discourse to a high degree is defined through the use of this rhetorical device. Furthermore, to the extent that we internalize metalepsis as a figure of thought (in the sense of Quintilian (Institutio oratoria, IX.i. 19-21)), it could be argued that the figure defines the contradictory ideology of contemporary consumption culture, as in the words of Barbara Kruger: "I shop therefore I am". ${ }^{12}$ In order to understand the significance of advertising discourse for contemporary culture, it is necessary to take a look at the relation between art and advertising, and more generally at the relation between culture and mass media. 


\section{Art, Advertising Media, and Popular Culture}

The relations between art and mass media are complex, and can be analysed from a historical and contemporary perspective as well as formally and theoretically. Whereas art and media to a certain extent are coextensive (art is always presented in some media or other), art and mass media are often understood as mutually exclusive. Mass (re) production of cultural artefacts has frequently been seen as constituting a threat to artistic content and to higher cultural values. As early as Plato the reproduction of speech through writing was viewed as a threat to the educated and exclusive culture of a social elite (Plato, Phaedrus, 274d-275e). The invention of the printing press did not turn poetry into a popular cultural form, yet the form of fiction that the press made possible, the popular novel, did not become accepted as an art form until Romanticism (which also turned poetry into "literature"). ${ }^{13}$ With the arrival of an increasing number of new media technologies in the nineteenth and twentieth centuries, mass media became a social reality, which together with industrialization and urbanization effected a deep structural transformation of Western culture. It is also during this historical period, 1880-1930, that the culture of the popular classes underwent profound changes that were perceived by many as affecting and also threatening the domain of elite culture (Leavis 1930). Modernism in art and literature constitute direct and indirect reactions and responses to these events (Jameson 1979: 16).

As noted by Stuart Hall, the closer one looks at this moment in history, the more convinced one becomes that "somewhere in this period lies the matrix of factors and problems from which our history - and our particular dilemmas - arise" (Hall 1981: 229). In fact, during this period everything changes: it is not merely a shift in the relations of forces, but "a reconstitution of the terrain of political struggle itself" (Hall 1981: 229). Hence it is not by accident that so many of the characteristic forms of what we now think of as 'traditional' popular culture emerge in their distinctive modern form in this period. One of the most important forms of popular culture that emerges and take distinctive shape at this time is advertising and consumer culture (Schudson 1993: 147-177; Wernick 1994: 1-21).

There is no agreement among scholars as how to understand the concepts 'popular' and 'culture', nor how to describe the relation between them. There are not many today who would argue that popular culture is merely a product of the culture industries, but neither is the 'appropriation' of media products by the people seen as a genuine expression of popular (working or middle-class) culture. Instead, popular culture is more often conceived as an arena for both cultural and ideological conflict where the meaning of culture - both consumer culture and high culture - is at stake. As Fredric Jameson writes in an essay from 1979, the agonistic and dialectic relationship effects both an aestheticization of the commodity and a commodification of the art object (Jameson 1979: 9-13). This has a number of important consequences, the most important one in this context being the gradual rapprochement and approximation of art and advertising media. Not only do artists move between the fields, either by economic necessity or by desire to communicate, but advertising has through its short history made ample use of art, by direct and indirect quotations both from historical periods and from the contemporary scene. Increasingly, one also finds that artists - such as Jenny Holzer, Jeff Koons, Barbara Kruger, Les Levine, Otto Mittmannsgruber and Martin Strauß - make use of advertising strategies in their art and also appropriate the sites of advertising media 
(Dahlberg 2006; Bryan-Wilson 2008). In contrast to the art gallery and the museum, these sites are anonymous: public transportation, places of consumption and popular entertainment. The approximation of art and advertising within the realm of consumer culture also affects our attitude to advertisement. As Jean Baudrillard has stated, advertisements today are less a determinant of consumption than objects of consumption themselves (Baudrillard 1996: 173-174). With this autotelic and metaleptic figure, it is now time to return to the use of metalepsis in advertising media.

\section{Advertising as Metalepsis}

The typical advertisement in any medium is a compound, normally consisting of four elements: depiction of the product (or product package); graphical representation of brand name as logotype; image ('art'); and verbal elements ('copy') (Fowles 1996: 11, $45,83-87,169)$. The advertisement is usually constructed in such a way that on the one hand product and brand name constitute a synecdochic unit (as part and whole), and on the other hand the iconic and verbal elements are connected by what Roland Barthes termed anchorage and release (Barthes 1964). These two sides (or 'hands') of the advertisement are then very often connected by metalepsis. Taking the above-mentioned 1960s Esso advertisement as example, the product is depicted by the petrol pump (the package) on which the brand name and logotype is affixed. The logotype is also repeated in the lower right-hand corner of the advertisement. ${ }^{14}$ The image of the tiger on top of the car is anchored by the text above ("Put a tiger in your tank!") and released by the text below ("New power-formula Esso Extra gasoline boosts power three ways: ..."). The metaleptical relation between branded product and image-cum-text in the Esso advertisement has been described above and need not be repeated. However, one should note that this advertisement probably would not be as effective today, since petrol now is considered a generic product and the majority of people do not believe that one brand is better than another. ${ }^{15}$

Although this describes the typical advertisement also in our own day, there are many variations of and deviations from it. It is possible to leave out either the image or the verbal element (or both). For example, classified advertisements only contain information that pertains directly to the commodity; and advertisements for after-Christmas sales typically only contain information about the store name and location together with the copy "sale" (although this may, of course, be read as an iconic representation of a sale sign in a shopping window). These, in contrast to the compound advertisement for Esso, are often called simple advertisements (Fowles 1996: 11). In recent years it has become increasingly common in some types of advertisement to leave out the product, as for example in sports advertisements for Nike, although this is still a deviation from the norm in most other types of advertising (Berger 2001: 148-181 et passim). For obvious reasons, it is very rare to leave out the logotype, although it does happen. ${ }^{16}$ To leave out the brand name altogether from an advertisement would be an oxymoron, unless it is an advertisement for a product category or a generic product.

In the same way as one may vary and deviate from the typical advertisement, it is expected that an interesting advertisement should play around with the semiotic relations between the four described elements. Furthermore, the typical advertisement has direct and indirect relations to the product (depicted or not) and to the producer (brand); 
they also have complicated intertextual relations to other advertisements in the same campaign, to previous campaigns, to advertisements for other products or other brands (as in the implied reference to Hertz car rental in the slogan for Avis: "We're number two, we try harder") (Schudson 1993: 57), as well as to cultural and popular cultural meanings at large (Wernick 1994: 22-47 et passim; Fowles 1996: 90-93 et passim). To return again to the tiger figure, the meaning of the tiger as a symbol of power is fairly stable in contemporary culture, but in other times and places it would rather signify fear and danger. In Asia the tiger is generally seen as a symbol of power and strength, associated with the power and might of kings (in Korea the tiger is called the "King of the Animals"), but also of destruction and violence. We meet the latter figure in The Jungle Book (1894), where Rudyard Kipling presents the tiger Shere Khan as a mean and fearful figure. In Hinduism the god Shiva, in his aspect of the destroyer, is depicted wearing a tiger skin and riding a tiger. In China, tiger images are used as charms to ward off evil.

As should be evident from my analysis of the Esso advertisement, there is a strong argumentative aspect of advertising. However, it is contested how and on what level the persuasion operates. While some would argue that advertising acts on our subconscious, persuading without engaging the reader rationally, others maintain that advertising contains arguments that the consumer evaluates both consciously and carefully. In an article arguing in defence of advertising as rational argumentation, Christina Slade gives an example of a Spanish television commercial for the beer Dos X (Slade 2002: 157 178). The commercial shows an image of a refrigerator, opening to show it filled with beer, then closing and opening with less beer, and then again closing and opening, this time again filled with beer. The copy to the commercial, anchoring the images, states succinctly: "Now you understand the evolution of species" (Slade 2002: 170). ${ }^{17}$ As in all good advertisements, this copy is open to several interpretations. The intended or preferred meaning is probably that Dos $\mathrm{X}$ has proven that it is the best by its ability to survive in the refrigerator environment: it has achieved natural selection. Although there obviously is rational persuasion at work here, and an argumentation that demands of the viewer an intellectual effort to decode the message, what makes the Dos $\mathrm{X}$ advertisement work as advertising is not the validity of the argument but that we enjoy and remember it. As in the case of the Esso advertisement, it is the figurative language - verbal and visual - that delivers the message.

In rhetorical terms it is a question of catching the audience's attention and of creating goodwill towards the speaker (captatio benevolentiae); of maintaining the audience's interest by using varied and elaborate language (eloquentia); and of ending the message with an engaging and memorable conclusion (peroratio) that moves the consumer to purchase. In an interesting empirical and text-interpretive study on reader-response of the visual rhetoric of advertising, Edward McQuarrie and David Glen Mick have tried to show that the use of visual figuration - such as rhyme, antithesis, metaphor, and paronomasia - leads to a more favourable attitude toward an advertisement (McQuarrie \& Mick 1999). In their study, they also show that the effect of some tropes - like metaphor and pun-diminished or disappeared if the reader lacked the proper cultural competence. One could generalize by saying that knowledge of various aspects of popular culture and its stereotypes are crucial for decoding the predominant iconic language of advertising. However, since advertising itself constitutes a significant element in popular culture, the 
inverse is also true (Twitchell 1996). Hence a person whose understanding of the tiger as cultural icon has not been formed by the Esso advertising might be unable to decode the locution "Put a tiger in your tank". For example, the expression was used in connection with the release of Apple's new operating system OS X Tiger in 2005 (DeMaria 2005). Perhaps a teenager of today (and not necessarily a World War II enthusiast) would believe that the expression referred to the German Tiger tank?

Although the views on how advertising operates vary both among researchers and between agencies, clients and interest groups, and policy makers, there is some degree of consensus that certain groups should be protected from direct commercial interpellation (Schudson 1993: 120-121). It is in particular children that cause concern, and in several countries there exist media regulations - either self-imposed or through government legislation - to ensure the protection of this exposed group (Barendt \& Hitchens 2000: 232-234). However, if it is not possible to address the youngest through advertising media, one can instead make use of the product package. In fact, the oldest place to put an advertisement is on the package itself (Wernick 1994: 1-11). On the breakfast tables in most Western countries one finds both milk packages (often containing advertisements for other diary products) and cereal boxes. A sweet example of the latter is Kellogg's Frosties (initially called Sugar Frosted Flakes), a cornflakes cereal with approximately $40 \%$ added sugar. On the packages of Frosties one finds Tony the Tiger, who was created in 1951 in a campaign for Kellogg's new sugar-frosted cereal (see figure 2).

Figure 2. Tony the Tiger

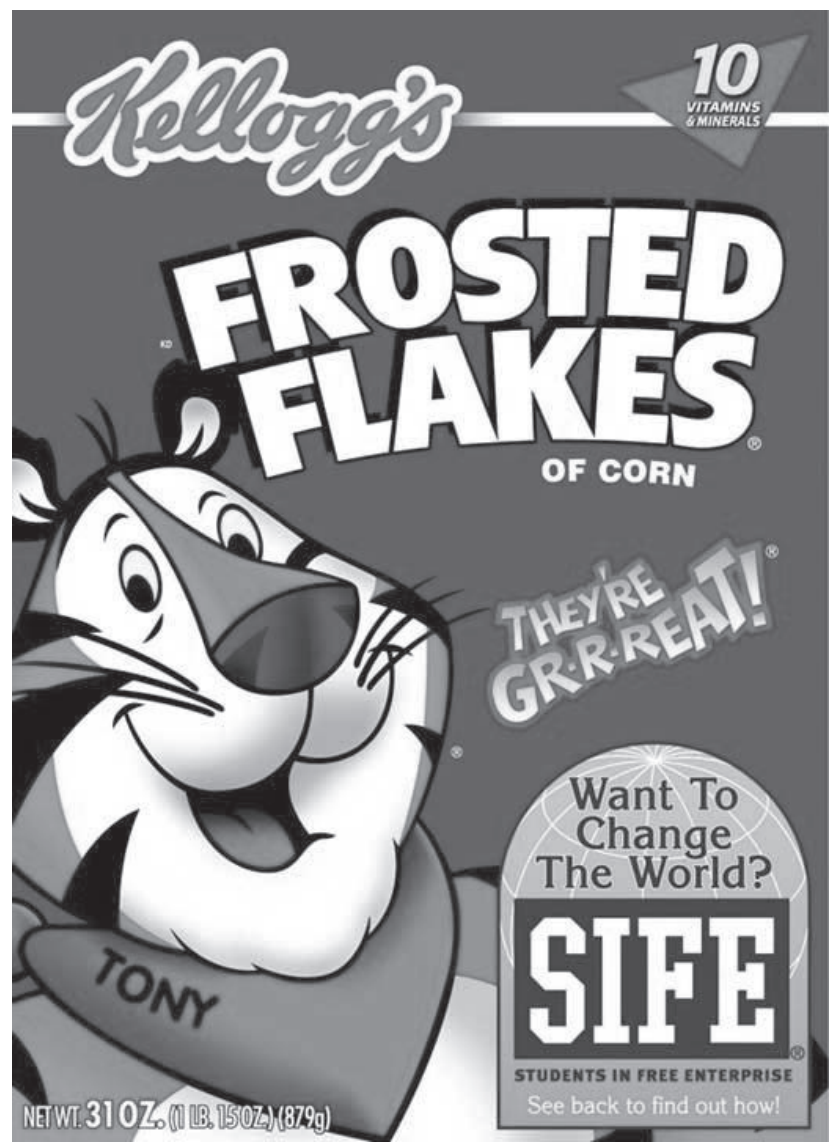


There were originally four animated animals created to sell the cereal, but Tony quickly edged out Katy the Kangaroo, Newt the Gnu and Elmo the Elephant to become the sole star of Kellogg's advertisement efforts. Tony's original designer, children's book illustrator Martin Provinsen, first created an orange cat with black stripes and a blue nose, and that walked on all fours. However, like most celebrities, Tony has undergone extensive cosmetic changes over the decades. His head has become more round in shape, and his eye colour has changed from green to gold. He has also gained stature from a scrawny, cereal-size pussycat to a two-metre figure with a towering, upright stance and a slim, muscular physique. Tony does not, of course, only appear on cereal packages, but can also be found in cartoons, television commercials and on Kellogg's website (www. kelloggs.com). In contrast to the Esso tiger, Tony is scripted so that children can relate to him as a friend and role model, and he is in turn surrounded by his own tiger family. Yet Tony also functions as a metaphorical metalepsis, as the tiger in the Esso advertisement. In the following copy from a television commercial, the metalepsis is quite explicit:

\author{
Show'em you're a tiger \\ Show'em what you can do \\ The taste of Tony's Frosted Flakes \\ Brings out the tiger in you, in you!
}

The copy has a direct address ('you') and contains the kind of exhortation that parents and coaches give children: show me (and others) that you are an achiever, that you can do things, that "you're a tiger". However, the copy does not say that putting Kellogg's Frosties in your tummy turns you into a tiger; instead the metaleptic future effect is related to 'taste' as catalytic rather than substantive cause. In fact, according to the copy "you" already are a tiger. In this way the interpellation performs the same transformation that the copy ascribes to the sweet flavour of the cereal. In contrast to the catalytic and performative metalepsis of Tony the Tiger, in a recent advertisement for Accenture (a "global management consulting, technology services and outsourcing company") there was a direct admonishment to be a tiger: "Go on. Be a Tiger". ${ }^{18}$ However, the tiger referred to in the copy is not a feline animal but the professional golf player Tiger Woods, who is said to represent "the modern day personification of high performance".

\title{
Conclusion
}

As has been shown in this article, as rhetorical figure metalepsis is widely used both in art and in mass media discourse, and is also used in different ways. In the article particular attention has been paid to the use of metalepsis in advertising media, and also to the homology between this figure and contemporary consumer culture. Although not discussed in the article, it could be mentioned that metalepsis is also a prominent - if not defining - feature of interactive media. In this form of new media, the user is represented as an agent in the diegesis and it is crucial that he or she has the experience of being in control of the actions and events taking place in the diegesis. In other words, since interactive media is structured as a relation between input and output, between cause and effect, one could say that it is structured like a metonymy. However, the reality of interactive media (just like the reality of mass media) is not that the user (or consumer) is really in control, only that he/she perceives it in this way. The user cannot control 
the design of the interface, and the effects of his/her interactions with the medium are not so much a result of his/her actions as of the ("interactive") structure of the interface itself. Hence we have (again) a case of inverted metonymy, that is metalepsis. It could therefore be argued that media metalepsis, due to the ever-increasing presence of advertising discourse and of interactive media in contemporary society, is turning into the most important rhetorical figure of our time.

\section{Notes}

1. An earlier version of this essay was presented at the conference Litteratur, teknologi, fantasi, at the Norwegian University of Science and Technology (NTNU), Trondheim, August 18-21, 2005.

2. ["une espèce de métonymie, par laquelle on explique ce qui suit pour faire entendre ce qui précède; ou ce qui précède pour faire entendre ce qui suit."]

3. ["nous mettent devant les yeux le fait que la description suppose."]

4. [“à faire entendre une chose par une autre, qui la précède, la suit ou l'accompagne, en est un adjoint, une circonstance quelconque, ou enfin s'y rattache ou s'y rapporte de manière à rappeler aussitôt à l'esprit."]

5. ["métalepse de l'auteur"; "le tour par lequel un poète, un écrivain, est représenté ou se représente comme produisant lui-même ce qu'il ne fait au fond, que raconter ou décrire."]

6. This example is borrowed from Schaeffer 2005.

7. For discussion of this passage in Aristophanes' Clouds, see MacDowell 1995: 134-136.

8. That would be the case of the modern kind of parabasis that goes under the name of 'romantic irony', see e.g. Szondi 1948.

9. This example is borrowed from Genette 2004: 58 .

10. For discussion of media as system, see Luhmann 1996.

11. For interesting discussions of images of smoking in media and advertising, see Schudson 1993:178-208, and Torell 2002.

12. Barbara Kruger, "Untitled (I shop therefore I am)", photographic screenprint on vinyl, 1987, private collection.

13. For discussions of the historical effects of printing on literature (both poetry and prose), see Ong 1988: 139-155, Martin 1994: 283-330. For a critical discussion of the gentrification of the novel, see LacoueLabarthe and Nancy 1978.

14. Although the brand logotype almost always is placed in the bottom right corner of an advertisements, there are (of course) deviations from the normative position, as e.g. in many advertisements for Diesel brand clothing.

15. This observation I owe to advertising agent Pelle Hasselgren, personal communication.

16. See the "Monolog des Vertrauens" by Otto Mittmannsgruber and Martin Strauß (1995 \& 1999), discussed in Dahlberg 2006.

17. [“Ahora entenderás la evolución de las especas."].

18. See http://www.accenture.com/ (accessed January 2006).

\section{References}

Aristophanes (1998) Aristophanes II, Clouds. Wasps. Peace, ed. \& trans J. Henderson. Cambridge: Harvard University Press.

Barendt, Eric, \& Hitchens, Lesley (2000) Media Law. Cases and Materials. Harlow: Longman.

Barthes, Roland (1964) 'Rhétorique de l'image', Communications, 4 (1964).

Barthes, Roland (1968) 'L'Effet de réel', Communications, 11 (1968).

Baudrillard, Jean (1996) The System of Objects. London: Verso.

Berger, Warren (2001) Advertising Today. London: Phaidon.

Bryan-Wilson, Julia (2008) 'Signs and Symbols', Artforum, October 2008, pp. 165-168.

Burkhardt, Armin (2001) 'Metalepsis', in Gert Ueding (ed.), Historische Wörterbuch der Rhetorik, Bd. V. Tübingen: Max Niemeyer, 2001, pp. 1087-1099.

Dahlberg, Leif (2006) 'On the Open and Closed Space of Public Discourse', Nordicom Review 27 (2006) 2, pp. 35-52.

DeMaria, Mike (2005) 'Put a Tiger in Your Tank (Apple's Mac OS X 10.4.)', Network Computing, June 9, 2005 (http://www.networkcomputing.com). 
Dumarsais (1988) Des Tropes, ou Des Différents sens. Paris: Flammarion.

Ewen, Stuart (1976) Captains of Consciousnesses. Advertising and the Social Roots of Consumer Culture. New York: McGraw-Hill.

Fontanier, Pierre (1977) Les Figures de discours, ed. G. Genette. Paris: Flammarion.

Fowles, Jib (1996) Advertising and Popular Culture. Thousand Oaks: Sage.

Genette, Gérard (1972) 'Discours du récit', in his Figures III. Paris: Seuil, 1972, pp. 65-281.

Genette, Gérard (2004) Métalepse. De la figure à la fiction. Paris: Seuil.

Gibbons, Joan (2005) Art and Advertising. London: I.B. Tauris.

Goffman, Erving (1969) The Presentation of Self in Everyday Life. Harmondsworth: Penguin.

Goffman, Erving (1986) Frame Analysis. An Essay on the Organization of Experience. Boston: Northeastern University Press.

Hall, Stuart (1981) 'Notes on Deconstructing the Popular', in R. Samuel (ed.), People 's History and Socialist Theory. London: Routledge \& Kegan Paul, 1981, pp. 227-240.

Jameson, Fredric (1979) 'Reification and Utopia in Mass Culture', in Signatures of the Visible. New York: Routledge, 1990, pp. 9-34.

Lacoue-Labarthe, Philippe, \& Nancy, Jean-Luc (1978) L'Absolu littéraire. Théorie de la littérature du romantisme allemand. Paris: Seuil.

Leavis, Frank Raymond (1930) Mass Civilisation and Minority Culture. Cambridge: Minority Press.

Luhmann, Niklas (1996) Die Realität der Massenmedien, 2., erweiterte Aufl. Opladen: Westdeutscher Verlag.

MacDowell, Douglas (1995) Aristophanes and Athens. Oxford: Oxford University Press.

Martin, Henri-Jean (1994) The History and Power of Writing, trans. L. G. Cochrane. Chicago: University of Chicago Press.

McLuhan, Marshall (2002) The Mechanical Bride. Folklore of Industrial Man. Corte Madera: Ginko Press.

McQuarrie, Edward F., \& Mick, David Glen (1999) 'Visual Rhetoric in Advertising: Text-Interpretive, Experimental, and Reader-Response Analyses', Journal of Consumer Research, Vol. 26 (June 1999), pp. 37-54.

Ong, Walter J. (1988) Orality and Literacy. The Technologizing of the Word. London: Routledge.

Quintilian (2002) The Orator's Education, ed. \& trans. D.A. Russell. Cambridge: Harvard University Press.

Roque, Georges (2005) 'Sous le signe de Magritte', in John Pier \& Jean-Marie Schaeffer (eds.), Métalepses. Entorses au pacte de la représentation. Collection «Recherches d'histoire et de sciences sociales» 108. Paris: EHESS, 2005, pp. 263-276.

Roussin, Philippe (2005) 'Rhétorique de la métalepse, états de cause, typologie, récit', in John Pier \& JeanMarie Schaeffer (eds.), Métalepses. Entorses au pacte de la représentation. Collection «Recherches d'histoire et de sciences sociales» 108. Paris: EHESS, 2005, pp. 37-58.

Schaeffer, Jean-Marie (2005) 'Métalepse et immersion fictionelle', in John Pier \& Jean-Marie Schaeffer (eds.) 'Métalepses. Entorses au pacte de la représentation. Collection «Recherches d'histoire et de sciences sociales» 108. Paris: EHESS, 2005, pp. 323-334.

Schudson, Michael (1993) Advertising, the Uneasy Persuasion. Its Dubious Impact on American Society. London: Routledge.

Slade, Christina (2002) 'Reasons to Buy: The Logic of Advertising', Argumentation, Vol. 16 (2002), pp. 157-178.

Stanitzeck, Georg (2005) 'Texts and Paratexts in Media', Critical Inquiry, Vol. 32, No. 1 (Autumn 2005), pp. 27-42.

Szondi, Peter (1948) 'Friedrich Schlegel und die Romantische Ironie. Mit einer Beilage über Tiecks Komödie', in his Satz und Gegensatz: Sechs Essays. Frankfurt a. M.: Suhrkamp, 1976, pp. 71-78 .

Torell, Ulrika (2002) Den rökande människan. Bilden av Tobaksbruk i Sverige mellan 1950- och 1990-tal. Stockholm: Carlssons.

Twitchell, James B. (1996) Adcult USA. The Triumph of Advertising in American Culture. New York: Columbia University Press.

Wernick, Andrew (1994) Promotional Culture. Advertising, Ideology, and Symbolic Expression. London: Sage.

LEIF DAHLBERG, Ph.D., Associate Professor, Director of Studies, School of Computer Science and Communication, Royal Institute of Technology, Stockholm, dahlberg@kth.se 